Vol. 1, No. 2, 2019

DOI 10.23939/jtbp2019.02.037

Vasyl Zhelykh, Olena Savchenko, Yuriy Furdas, Khrystyna Kozak, Khrystyna Myroniuk

\title{
ENERGY POTENTIAL OF CROP WASTE IN HEAT SUPPLY SYSTEMS
}

\author{
Lviv Polytechnic National University, Lviv, Ukraine \\ cr_i@ukr.net
}

(C) Zhelykh V., Savchenko O., Furdas Y., Kozak K., Myroniuk K., 2019

One of the most promising components of Ukraine's renewable energy is bioenergy. It is based on the use of biomass, which is the raw material for the production of solid, liquid and gaseous fuels. Biomass includes agricultural waste and residues, wood waste in the forestry, woodworking and pulp and paper industries, energy crops, organic part of industrial and household waste. Ukraine possesses large areas of land resources, has favorable soil and climatic conditions and developed agriculture, so it can successfully develop bioenergy based on plant biomass. It is most advisable to convert crop waste to biogas, which will allow agricultural enterprises to obtain an additional source of energy and ensure the production of high quality organic fertilizers. In addition, biogas production is environmentally friendly because it does not cause additional remission of greenhouse gas and reduces the amount of organic waste. Biogas is easy to use for energy purposes, finds use in decentralized block heat plants for electricity and heat, can be fed into an existing gas transmission network and used as motor fuel for cars. This article presents a methodology for determining the amount of biogas and analytical studies of methane formation in a household biogas plant from crop waste, including corn stalks, grass, grape leaves, sugar beet leaves, cereal straw, red clover hay, straw. The analysis of the results of analytical studies shows that the most biogas is produced from grasses, cereals and corn.

Key words: bioenergy; biomass; energy potential; biogas, plant waste.

\section{Introduction}

In Ukraine there is considerable potential of alternative energy sources, with the greatest energy potential being seen in the energy of biomass, a renewable substance of organic origin [Geletukha and Zhelyzensa, 2017]. The use of biomass is agricultural waste and residues, timber waste in the forestry, wood processing and pulp and paper industries, energy crops, organic part of industrial and household waste [Klašnja et al., 2013], [Irmak, 2016], [Mikkola and Ahokas, 2011]. The use of biomass has several advantages: it belongs to the renewable energy sources, its use will allow to reduce the amount of waste of different sectors of the economy, when burning biomass gases are not generated, which contribute to the greenhouse effect, and accordingly improves the environmental state of the environment.

Biomass is used for the production of thermal and electrical energy, whereby the methods of producing energy from biomass are based on the processes of direct combustion, pyrolysis, gasification, liquefaction, extraction, transesterification, anaerobic fermentation, fermentation [Savchenko et al., 2018], [Zhelykh et al., 2016], [Prins and Dahmen, 2015], [Deshmukh et al., 2013]. The main products of these processes are solid (firewood, briquettes, fuel pellets), liquid (biomethanol, bioethanol, biodiesel) or gaseous (biogas, biohydrogen) fuel [Robak and Balcerek, 2018], [Xue Li et al., 2017].

In heat supply systems, organic biomass processing products are most often used as a source of energy in heating installations [Zao, 2017], [Konrad et al., 2017]. 
Thus, one of the effective ways of supplementing and replacing traditional fuel and energy resources is the production and use of biogas. Biogas is easy to use and finds use at decentralized block heat plants for electricity and heat or can be fed into an existing gas transmission network.

The exhaustiveness of hydrocarbon energy resources, the general upward trend in the cost of their production, the expected increase in the payment for greenhouse gas emissions are gradually making biogas profitable. An additional benefit is the ability to dispose of agricultural plant waste. Therefore, the interest was caused by determining the amount of biogas output from crop waste at different fermentation times.

The purpose of the work is to perform an assessment of the energy potential of crop waste and the amount of biogas that can be generated from agricultural waste in a household biogas plant.

The object and methods of research. Use of agricultural plant waste for biogas production.

Research results. Crop waste is divided into primary and secondary. Primary agricultural wastes include cereals, legumes, maize waste, and sunflower. They are formed directly in the harvesting process of the respective crops. Secondary agricultural waste includes waste that is produced during the processing of the crop (sunflower husks, rice husks, sugar beet pulp, etc.) [Saidura et al., 2011]. The use of crop waste for energy depends on the nature of large-area crops and the amount of residues that can be obtained from a unit of acreage. A credible assessment of the biomass energy potential is based on the calculation of three types of potential: theoretical, technical and economic. The theoretical potential is the total maximum amount of biomass that can theoretically be used for energy production. Technical potential is a fraction of the theoretical potential that is physically available at the current state of the art and technology. Economic potential is a fraction of the technical potential that satisfies the criteria of economic feasibility and takes into account other consumers of this type of biomass [Litvak, 2015]. The biomass energy potential of crop waste and their primary and secondary waste is estimated using statistical data on gross crop yields. The energy potential of crop wastes for the most common crop types is presented in Table 1 [Pivniak and Shkrabets, 2013].

Table 1

\section{Energy potential of crop production waste in Ukraine}

\begin{tabular}{|c|c|c|}
\hline No. & Type of agricultural waste & Energy potential, million tonnes/year \\
\hline 1 & Cereal straw & 5.6 \\
\hline 2 & Stems, corn cobs & 2.4 \\
\hline 3 & Sunflower stems and husks & 2.3 \\
\hline 4 & Wood waste & 2.0 \\
\hline
\end{tabular}

The output of biogas depends on many factors, including the temperature of anaerobic fermentation, the type and concentration of bacteria, the method of mixing the substrate, the duration of the process and the nutrients of the substrate [Korolov and Maikov, 2012]. In addition, the amount of biogas produced depends on the method of grinding the organic mass [Pavlitsky et al., 2015], the content of dry matter in the biomass and the organic matter in the dry biomass [Soroka et al., 2016]. Therefore, the results of studies on the composition and amount of biogas presented in Ukrainian and foreign publications are quite different. Table 2 provides information on biogas output from different crop wastes [Feduniak, 2014]. 
As can be seen from Table 2, the highest biogas yield per tonne of waste is observed for corn waste for grain and sugar beet stacks. To calculate the estimated volume of biogas produced, we use the method of determining the volume of biogas from solid household waste and adapting it to plant waste.

The initial data for the calculation are the biomass temperature, ${ }^{\circ} \mathrm{C}$; biomass humidity $\mathrm{W}, \%$; ash content of dry crop waste $\mathrm{A}, \%$. The calculation is performed in the following sequence.

Table 2

Amount of biogas from plant waste

\begin{tabular}{|c|c|c|}
\hline No. & Type of agricultural waste & Biogas output, $\mathrm{m}^{3} /$ ton \\
\hline 1 & Wheat straw & 342 \\
\hline 2 & Barley straw & 342 \\
\hline 3 & Corn stalks on grain & 420 \\
\hline 4 & Sugar beet branch & 426 \\
\hline & Sunflower stems & 180 \\
\hline & Potato dumplings & 350 \\
\hline & Hog and stems of vegetables & 300 \\
\hline
\end{tabular}

Determined the concentration of organic matter, $\mathrm{kg} / \mathrm{m}^{3}$ :

$$
\mathrm{S}=\rho_{\mathrm{V}} \cdot(100-\mathrm{W}) \cdot(100-\mathrm{A}) \cdot 10^{-4},
$$

where $\mathrm{W}$ is the biomass moisture content, $\%$; $\mathrm{A}$ - the ash content of dry organic raw materials, $\%$; $\rho_{\mathrm{v}}$ is the biomass density, $\mathrm{kg} / \mathrm{m}^{3}$ :

$$
\rho_{V}=\frac{\rho_{\text {out }}}{100+W \cdot\left(\rho_{\text {out }} \cdot 10^{-3}-1\right)} \cdot 100,
$$

where $\rho_{\text {out }}-$ the density of the solid biomass fraction, $\mathrm{kg} / \mathrm{m}^{3}$.

The kinematic coefficient, $\mathrm{K}$, is defined as:

$$
\mathrm{K}=\mathrm{K}_{\mathrm{r}}\left(\mu_{\mathrm{m}} \cdot \mathrm{S}-\mathrm{d}\right) /\left(\mathrm{B} \cdot \mathrm{S}-\mathrm{K}_{\mathrm{r}} \cdot \mathrm{d}\right),
$$

where $\mathrm{d}$ is the daily load of biogas, $\mathrm{kg} /\left(\mathrm{m}^{3} /\right.$ day $) ; \mu_{\mathrm{m}}$ - the maximum growth rate of microorganisms, microns; $K_{\mathrm{r}}$ is the coefficient of proportionality, which is determined by the formula:

$$
K_{r}=\frac{(38 \cdot S-205) \cdot P}{100 \cdot\left(t_{B}-17,8\right)} \text {. }
$$

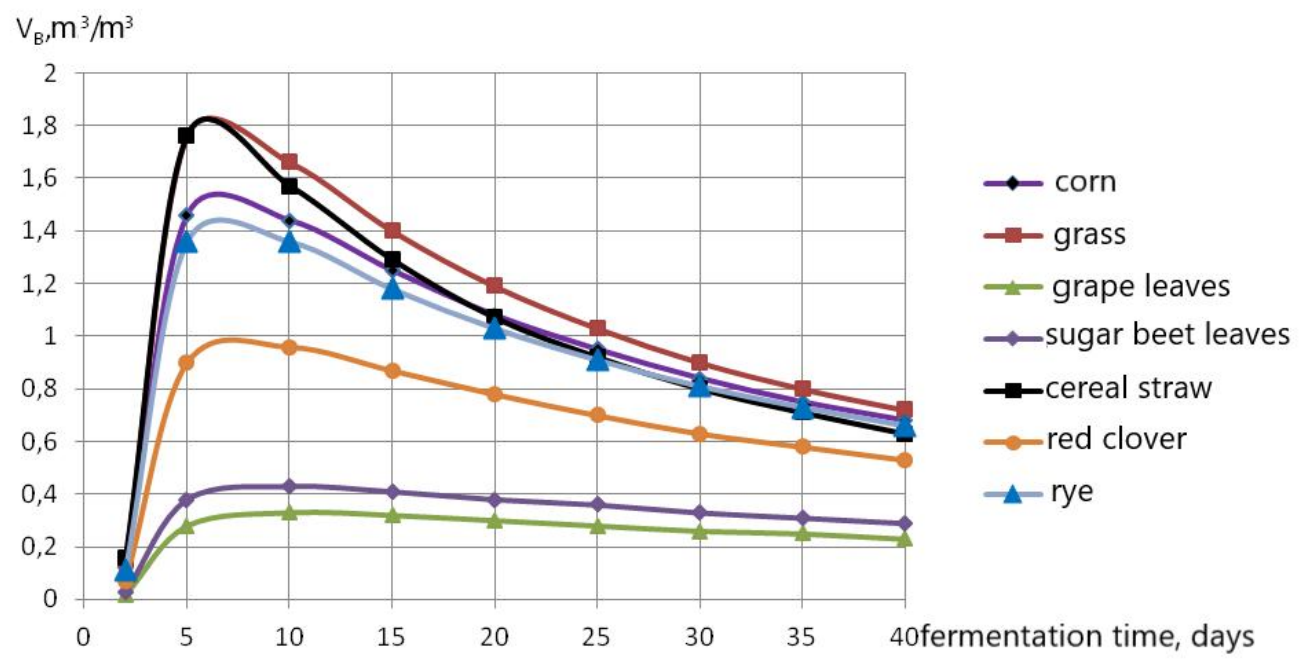

Daily output of biogas depending on the time of fermentation for different wastes of agricultural plants 
The maximum growth rate of microorganisms, $\mu_{\mathrm{m}}$, microns, in biomass, is as follows:

$$
\mu_{m}=0.013 \cdot t_{i n}-0.129
$$

where $t_{\text {in }}$ is the substrate temperature, ${ }^{\circ} \mathrm{C}$.

Daily output of biogas, $\mathrm{m}^{3} / \mathrm{m}^{3}$ :

$$
\mathrm{V}_{\mathrm{B}}=\frac{\mathrm{B} \cdot \mathrm{S}}{\tau}\left(1-\frac{\mathrm{K}}{\tau \cdot \mu_{\mathrm{m}}-1+\mathrm{K}}\right),
$$

where $\mathrm{B}$ is the maximum biogas yield, $\mathrm{m}^{3} / \mathrm{kg} ; \mathrm{S}-$ the concentration of organic matter in biomass, $\mathrm{kg} / \mathrm{m}^{3}$; $\tau$ - fermentation time, days.

The calculation was carried out for a bioreactor with a volume of $1.2 \mathrm{~m}^{3}$ [Zhelykh and Furdas, 2011]. The amount of feed biomass was $1.0 \mathrm{~m}^{3}$. The temperature of the organic mass in the bioreactor was assumed to be $50{ }^{\circ} \mathrm{C}$. The following organic wastes were used as organic raw materials: agricultural crops, corn stalks, grass, grape leaves, sugar beet leaves, cereal straw, red clover hay, rye straw. For these wastes, the daily output of biogas VB was determined depending on the fermentation time $\tau$, the results of the calculation are shown in Figure.

As shown in Figure 1, the maximum daily output of biogas occurs 5-7 days after downloading the biomass in the bioreactor and the most-more biogas produced from grass, straw, grain and corn.

\section{Conclusions and practical significance}

1. An estimation of energy potential of crop wastes in agriculture of Ukraine is made. A promising trend is the processing of cereal straw, as the amount of this raw material remains large at present, as well as the corn stalks and sugar beet sprouts that have the highest biogas yield.

2. The dependence of the daily output of biogas on the time of fermentation of agricultural waste was determined, including corn stalks, grasses, grape leaves, sugar beet leaves, cereal straw, red clover hay, rye straw, in a household biogas plant.

3. It is proved that of the proposed biomass species, most of the biogas is produced from grasses, cereal straw and corn stalks, with the maximum daily output of biogas occurring 5-7 days after biomass loading into the bioreactor.

\section{References}

Geletukha G. G., Zhelyzensa T. A. (2017). Status and prospects of bioenergy development in Ukraine. Industrial heat engineering, 39, No. 2, pp. 60-64 (In Ukrainian).

Klašnja B., Orlović S., Galić Z. (2013). Comparison of Different Wood Species as Raw Materials for Bioenergy. South-East European Forestry, 4 (2), pp. 81-88.

Irmak S. (2016). Biomass as raw material for production of high value products. Biomass Volume Estimation and Valorization to Energy, pp. 201-225.

Mikkola H. J., Ahokas J. (2011). Renewable energy from agro biomass. Agronomy Research Biosystem Engineering Special, 1, pp. 159-164.

Savchenko O., Zhelykh V., Yurkevych Y., Kozak K., Bahmet S. (2018). Alternative energy source for heating system of woodworking enterprise. Energy Eng. Control Syst, 4, No. 1, pp. 27-30.

Zhelykh V., Furdas Y., Dzeryn O. (2016). Theoretical and experimental investigations of thermal conditions of household biogas plant. Selected Scientific Papers - Journal of Civil Engineering, 11(1), pp. 7-14.

Prins W., Dahmen N. (2015). Processes for thermochemical conversion of biomass. 10-th European conference on Industrial Furnaces and and Boilers. 8. 
Deshmukh R., Jacobson A., Chamberlin C., Kammen D. (2013). Thermal gasification or direct combustion. Comparison of advanced cogeneration systems in the sugarcane industry. Biomass and bioenergy, Vol. 55, pp. 163-174.

Robak K., Balcerek M. (2018). Review of Second Generation Bioethanol Production from Residual Biomass. Food Technology and Biotechnology, 56(2), pp. 174-187.

Xue Li, Yan-Hua Liu, Xin Zhang, Chang-Ming Ge, Ren-Zhe Piao, Wei-Dong Wang, Zong-Jun Cui, and Hong-Yan Zhao (2017). Evaluation of Biogas Production Performance and Dynamics of the Microbial Community in.

Konrád K., Viharos Zs. J., Németh G. (2017) Raw material measurement methods evaluation and ranking for pellet production. 15-th IMEKO TC10 Workshop on Technical Diagnostics: "Technical Diagnostics in CyberPhysical Era”, pp. 164-169.

Saidura R., Abdelaziza E. A., Demirbasb A., Hossaina M. S., Mekhilefc S. (2011). A review on biomass as a fuel for boilers. Renewable and Sustainable Energy Reviews, 15 (5), pp. 2262-2289.

Litvak O. A. (2015). Bioeconomic priorities in the development of the agrarian sector. Global and national problems of the economy, 8, pp. 200-205. (In Ukrainian)

Pivniak G. G., Shkrabets F. P. (2013). Alternative energy in Ukraine: Monographp. 109 (In Ukrainian).

Korolev S. A., Maikov D. V. (2012). Identification of the mathematical model and investigation of various modes of methanogenesis in the mesophilic medium. Computer research and simulation, 4, No. 1, pp. 131-141 (In Russian).

Pavlitsky V. M., Flonts I. V, Barilko N. V. (2015). Exit of biogas from herbaceous plants depending on the method of shredding. Scientific herald of the National University of Bioresources and Nature Management of Ukraine. Series: Biology, Biotechnology, Ecology, 214, pp. 222-228 (In Ukrainian).

Soroka A. V., Kostyuchenko N. N., Bryl Ye. A., Kuznetsov I. N. (2016). Evaluation of crops and biowaste production for biogas production in the conditions of the Brest region. Ecological Herald, 2 (36), pp. 92-96 (In Russian).

Feduniak I. O. Efficiency of biogas production in Ukraine. (2014). Scientific notes of Ostroh Academy National University. Series: Economics, 26, pp. 45-49 (In Ukrainian).

Zhelykh V. M., Furdas Yu. V. (2011). Patent of Ukraine No. 57360. Biogas reactor. Bul. 4, p. 2.

В. М. Желих, О. О. Савченко, Ю. В. Фурдас, Х. Р. Козак, Х. В. Миронюк Національний університет “Львівська політехніка", кафедра теплогазопостачання і вентиляції

\section{ЕНЕРГЕТИЧНИЙ ПОТЕНЦІАЛ ВІДХОДІВ РОСЛИННИЦТВА У СИСТЕМАХ ТЕПЛОГАЗОПОСТАЧАННЯ}

(С) Желих В. М., Саченко О. О., Фурдас Ю. В., Козак Х. Р., Миронюк Х. В., 2019

Однією з найперспективніших складових відновлюваної енергетики України є біоенергетика. Вона основана на використанні біомаси, яка слугує вихідною сировиною для виготовлення палива у твердому, рідкому та газоподібному станах. До біомаси зараховують відходи та залишки сільського господарства, відходи деревини у лісовому господарстві, деревообробній та целюлозно-паперовій промисловості, енергетичні культури, органічну частину промислових та побутових відходів. Україна володіє великими площами земельних ресурсів, має сприятливі грунтово-кліматологічні умови та розвинене сільське господарство, тому може успішно розвивати біоенергетику, основану на рослинній біомасі. Найдоцільніше відходи рослинництва переробляти на біогаз, який дасть змогу сільськогосподарським підприємствам отримати додаткове джерело енергії та забезпечить виробництво високоякісних органічних добрив. Крім того, виробництво біогазу не шкідливе для навколишнього середовища, оскільки не спричиняє додаткову ремісію парникового вуглекислого газу і зменшує кількість органічних відходів. Біогаз зручний у використанні для енергетичних потреб, 
знаходить застосування на децентралізованих блочних теплоцентралях для електро- $\mathrm{i}$ теплопостачання, може подаватися в газотранспортну мережу та використовуватися як моторне паливо для автомобілів. У статті запропоновано методику визначення кількості біогазу та проведено аналітичні дослідження метаноутворення у побутовій біогазовій установці з відходів рослинництва (це, зокрема, кукурудзяні стебла, трава, листя винограду, листя цукрових буряків, солома зернових культур, сіно червоної конюшини, солома жита). На підставі результатів аналітичних досліджень встановлено, що із запропонованих видів біомаси найбільше біогазу утворюється з трави, соломи зернових та кукурудзи.

Ключові слова: біоенергетика; біомаса; енергетичний потенціал; біогаз; відходи рослинництва. 